University of Warwick institutional repository: http://go.warwick.ac.uk/wrap

This paper is made available online in accordance with publisher policies. Please scroll down to view the document itself. Please refer to the repository record for this item and our policy information available from the repository home page for further information.

To see the final version of this paper please visit the publisher's website. Access to the published version may require a subscription.

Author(s): Riello, G., Lemire, B.

Article Title: East and west: textiles and fashion in Eurasia in the early modern period.

Year of publication: 2008

Link to published version: http://chnm.gmu.edu/jsh/index.html 


\section{EAST \& WEST: TEXTILES AND FASHION IN EARLY MODERN EUROPE}

\section{By Beverly Lemire \\ Giorgio Riello}

\author{
University of Alberta \\ University of Warwick
}

Fashion underpinned the commercial growth and cultural transformation of western society. ${ }^{1}$ From at least the sixteenth century, fashion's demotic stimuli unleashed desires across European social ranks. Never just a folly, fashion was integral to the expression of consumer preference, the structuring of markets and the reordering of society. Its development and articulation regularized and routinized consumer expenditure, practices critical to the advance of western economies. Thus, economic and cultural realms converge. Yet there are many elements of the rise and early articulation of fashion in the West that have not been fully explored. Many of the current theorists hold very narrow views, little recognizing the fundamental influences Asia exerted on Europe over many centuries. Global history has begun to challenge narrowly national or regional articulations of history, noting the critical connections that ebbed and flowed across continents and oceans. ${ }^{2}$ These ties are described by John and William McNeill as a web or "a set of connections that link people to one another." The McNeills further contend that, "In all such relationships, people communicate information and use that information to guide their future behavior. They also communicate, or transfer, useful technology, goods, crops, ideas, and much else." 3

Global history has not yet tackled the issue of fashion, and it is regrettable that prominent theorists of fashion's evolution still claim it was an exclusively western development, western in origins, in its evolution, a phenomenon that "took hold in the modern West and nowhere else." ${ }^{4}$ This conjecture has been refuted by historians of China like Craig Clunas and Timothy Brook. ${ }^{5}$ More research must be done on this essential question to uncover the patterns and expressions of this phenomenon. This paper does not attempt to address this fundamental question, but observes how fashion in the West developed through a combination of influences, which included powerful extrinsic factors, as well as intrinsic. Fashion, as a vital motivation of ephemeral wants, was culturally formed and chronologically discrete in its functions in many societies. This paper explores the articulations of fashion in Europe through one of the most revolutionary commodities to appear in western markets, painted and printed Indian cotton textiles. This commodity represents one of the most important Asian imports into Europe, a product widely consumed and ultimately a source of inspiration for European manufacturers. To understand the genesis of fashion in this period we must, therefore, recognize the significance of India in the culture and economy of Europe.

The printed cottons that flowed into Europe after 1500 strengthened fashion in that region of the world, while transforming its design idioms. Europe in this era lagged behind Indian centres of manufacture and commerce and looked 
east for various commodities including textiles. ${ }^{6}$ From the early sixteenth century, as the surge of imports increased, Europe struggled to respond to the forces unleashed by this commodity. The brilliance and fastness of colour and the striking designs of imported Indian cottons attracted generations of European consumers. Thus, Europe had an incentive to learn the "secrets" of calico printing (especially those of Indian and Ottoman artisans) in order to substitute homeproduced goods for imported commodities. Cotton textiles went beyond conspicuous consumption and contributed to a collective phenomenon which later historians and theoreticians have called fashion. But this process was not just an extension of trade, a passive adoption or diffusion of products, modes and manners. Europeans also shaped their own desires by engaging in the production of "exotic" commodities to feed expressed material demand. ${ }^{7}$ This was a motor of European development in the early modern period. Our paper concentrates on calico printing on cotton as a means to illuminate a critical disjuncture in European material culture. Fashion was not just created through the adoption and use of Asian goods; it was also shaped by a culture in which print was central, and it was the printing of information — visual, as well as literate-along with printing as a manufacturing process that produced a fashionability that could be fully communicated. The rise of the European calico printing industry in the late seventeenth and eighteenth centuries illustrates the importance of this commodity in the evolution of the fashion system. But Europe's debt to Asia began before the cotton trade expanded. It is to this early history that we turn first, examining the links between Asian commodities, sumptuary legislation and the evolution of fashion.

\section{II.}

Throughout the middle ages and the early modern period, commercial networks carrying Chinese silks and Indian cottons were jealously guarded, the trade goods from the silk road and the trade routes of the Indian Ocean and Red Sea sustaining generations of merchants, carriers and retailers. In this context, the Levant was a crucial gateway for Europe. ${ }^{8}$ Europe's loose and indirect ties to Asia before 1500 made this merchandise all the more desirable and the value and quality of iconic goods, like silk, also made them the focus of legislative and moral prescriptions. Silk, in particular, figured in the early articulations of new styles that flourished and intensified from the twelfth century onwards. SarahGrace Heller considers that the detailed descriptions given silks from China and Persia in Crusader literature were devised for an audience attentive to material expressions of style. She argues that this literary focus was contained in a genre read from Northern France to Iberia, which:

suggests that the vernacular public of this time had some consciousness of shopping, which is to say of calculating values in order to make personal purchases, an important clue for the presence of a fashion system because it is part of the act of making a personal choice to reflect individual taste, as opposed to an honorific vestimentary system, for example, where clothing is distributed by authorities to demonstrate status and favour in hierarchy, or in a system where choice is simply not an option. ${ }^{9}$ 
Literary texts offer a window on the desires of at least the tiny literate segment of society. Appetites heightened in the twelfth and thirteenth centuries through more intensive contact with the material riches of Ottoman society, as well as the fabrics trans-shipped from Asia through Levantine ports. Debate continues about the process of evolution of fashions and the ultimate genesis of a "fashion system", ${ }^{10}$ however, the importance of materials from China, India, Persia and Byzantium in this process is irrefutable. ${ }^{11}$ The arrival of growing quantities of silks in Europe realigned internal trade structures, as the desire for this commodity grew. ${ }^{12}$ At the same time, the spreading use of silks from these sources sparked recurring bouts of legislation aimed at constraining individual consumption. The diffusion of manufactures, like silk, through the commercial cities of Europe brought growing wealth to the first European regions to dominate this commerce - the Italian city states-where we find early evidence of the evolution of fashion. The silk industry first took root in Italy where merchants had long participated in the trade in silken draperies from Byzantine and Islamic territories. These commercial adventurers aspired to be part of what Anna Muthesius describes as "a silken hierarchy of dress" across the Mediterranean. ${ }^{13}$ Wealth, rather than birth, structured the societies in the most dynamic urban centres in Europe-Venice, Genoa, Florence-and in response

Figure 1

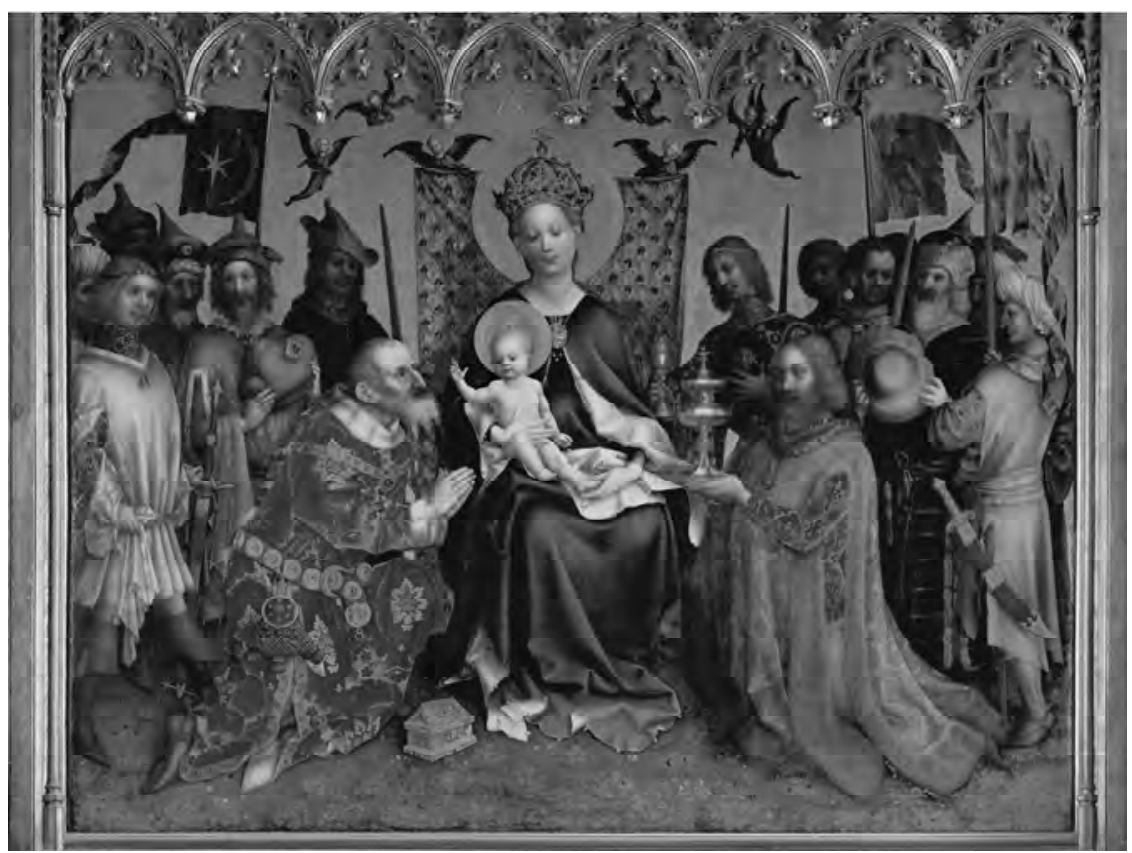

Stepan Lochner, The Adoration of the Magi, c. 1450, showing a variety of silks most of which would have come from the Middle East and Italy. Tempera on oakwood. Cathedral of Cologne, Germany. Photo Erich Lessing. (C) Art Resource, NY. 
to new articulations of dress and domestic accoutrements came renewed legislative interventions. Catherine Kovesi Killerby observes that "sumptuary legislation in Italy was primarily an urban phenomenon." ${ }^{14}$ Thriving city states brought opportunities for middle ranked men and women to construct their own material lives in new forms which produced an imbalance in a symbolic order that for centuries had equated status with birth. ${ }^{15}$ As identities could now be negotiated through changes in clothing, fashion became synonymous with social dynamism and its repression the aim of new regulations. ${ }^{16}$

Sumptuary laws were a punitive judicial response to material changes from those who venerated constancy in form as well as hierarchy - their targets were the families, groups and individuals whose aspirations surpassed their social standing. The numbers and frequency of sumptuary injunctions rose from the late middle ages, as commerce grew and the impulse to look fashionable shaped a new type of economic and cultural system. These laws mirror the processes of social and economic change. Products like silk were critical in the practice as the iconic reflection of commercial wealth and as the most desirable commodities. Aside from furs and precious metals, Indian, Chinese and Persian commodities were most commonly cited by legislators. Pearls worn in the hair or on clothes produced injunctions in Bologna, Florence and Genoa in the fourteenth century; and these were among the jewels most commonly brought from India. Similar prohibitions were passed in fifteenth-century Nuremburg and later in France. ${ }^{17}$ However, silks were without doubt the most contentious of late medieval and early modern commodities. ${ }^{18}$ They were carried west from China or made in Byzantium, Persia, India or (later) in Italy and were associated with secular or spiritual hierarchies for centuries. ${ }^{19}$ Whether as drapery for altars, pouches for reliquaries, vestments or formal robes, brocaded and embroidered silks were treasured by bishops and princes, despite the occasional censure of worldly clerics too well endowed with silken robes. ${ }^{20}$ Over the middle ages the passion persisted for these distinctive representations of esteem as silk became synonymous with Europe's elite (Figure 1). As the volume of silks in Europe grew their consumption spread beyond privileged circles and legal injunctions were repeated to try to arrest this spread. Regulation of material displays were directed at such celebrations as weddings, christenings and funerals. Displays of silks on these occasions-whether as plain cloth, velvet or satin, unadorned or embroidered - were judged equally abhorrent by Milanese and Venetian officials who insisted that no bedclothes, cushions or hangings of silken fabrics be employed for these events. ${ }^{21}$

These attempted restrictions were legislated at a time when considerable effort was being made by wealthy Europeans to design and decorate their domestic space in new and stylish ways. ${ }^{22}$ These material aspirations were seen to undermine traditional norms; however, wherever the trade routes carried cargoes of Asian goods across Europe official concerns emerged, marking both the vitality of trade and the social tumult this engendered. In Basel, Bern and Zurich citizens were forbidden to own or use christening bedclothes made of silk. New mothers and their female guests were likewise forbidden to wear headdresses or sleeves of satin or silk. ${ }^{23}$ This commerce brought wealth to European merchants and traders who re-channelled the flow of spices, textiles and other wares accumulated along the Asian trade routes, generating a new commercial energy in late 
medieval Europe that transformed cities and augmented the bourgeois classes. Well before direct contacts were established by sea, the flow of trade spread out from Venice through central Europe, re-orienting customs and trade patterns.

Over time, the target of the censors focused more intensively on clothing. Alan Hunt notes that in "the fifteenth century economic and cultural priority had shifted to Italy where sartorial attention focused on the silks and brocades coming from the Eastern Mediterranean and beyond." ${ }^{24}$ Women's clothing elicited the greatest volume of legislation in Italy; there and elsewhere in Europe, bourgeois women and men challenged the status quo of dress and claimed personal rights to self-expression in defiance of the authorities. ${ }^{25}$ Nevertheless, by the fifteenth century in Nuremberg, respectable burgers' wives were permitted to wear bands of silk on their cloaks, collars and sleeves to a prescribed depth, after officials had failed to enforce earlier bans. ${ }^{26}$ Even with this concession, officials remained concerned about the diffusion of silks through regional markets and the social disturbance it might evoke. ${ }^{27}$ After 1501 when direct sea-going traffic expanded between Europe and Asia, European governments and societies struggled to accommodate conflicting pressures: to preserve the existing hierarchies and to contain the tensions unleashed by social and economic change. All the while, the shifting aesthetics of fashion produced more and more fancies to enrapture consumers and enrage the beleaguered authorities. The reiteration and reissue of sumptuary regulation reflects the failures of governments to enforce restraint in order to preserve for the elites a monopoly on the use of commodities like silk. ${ }^{28}$

As already noted, one of the principal sources of new wealth for the mercantile classes was the trade in Asian commodities and, to a considerable extent, the most politically contested commodities in European societies were those goods imbued with an exotic allure; the sensuous sheen and drape of the silk cloth and the sparkle of silk ribbons were an affront to traditionalists. These authorities were willing to see these fabrics draped on cathedral alters or forming cardinals' robes but were offended to see them on the backs of burgers and their wives. The essence of fashion is its process of self-definition and adherence to change, which was exemplified in the reception of silks through the late medieval and early modern periods. Cardinal Francesco Gonzaga's inventory, for example, listed "turkish style" clothing, crimson and green "moorish" damasks, several kinds of velvets and silks and cushions of brocade "from Alexandria". ${ }^{29}$ The substance, design and colour of these goods were likewise a source of inspiration for men and women able to buy them and also for others eager to copy. In 1433, residents of Siena were limited by city ordinance to one pair of silk sleeves; but five years later a local silk industry was launched aiming to provide as much silk as the local citizenry required. By the sixteenth century, silk thread and cloth was being produced in several Italian cities (Florence, Lucca and Venice), and in a number of Spanish towns for local and European markets; while within the next century sericulture was established in France and attempted as far north as England though with more mixed outcomes. ${ }^{30}$

The influence of Asian commodities on the genesis of fashion in Europe was wide ranging, accelerating commerce, functioning as an economic driver; moreover, the material substance of this trade acted within social and cultural realms, as a stimulus of desires. ${ }^{31}$ These desires took material form, which in 
turn led to more extensive sumptuary laws, enacted with greater frequency from the fifteenth century onwards and directed specifically at dress. ${ }^{32}$ In the 1488 Zurich ordinance, the restraint of silk was the authorities' organizing precept, the material being banned on "coats, shoes, neckcloths, and such like, unless they belonged to the aristocratic gilds." Legislative enactment persisted through much of Europe inspired by both political and religious mores. Church courts in Switzerland, for example, continued with this agenda into the eighteenth century. ${ }^{33}$ And while all sumptuary regulation was repealed in England at the beginning of the seventeenth century, in 1684 Scottish women were chided for ignoring previous bans on "Flour'd, Strip'd, Figur'd Chequered, printed or painted Silk Stuff ... [and they] presum'd to go abroad with Cloathes made of the said prohibited Stuffs." 34

Overall, the trade in silks had profound effects on European markets and culture. The purpose of this survey has been to underline silk's importance as a precursor to Indian cottons and to illustrate the three-pronged reception in Europe to this fibre. First, as trade volumes grew, silks became significant markers of the culture of fashion spreading among ever-wider groups and types of people-from being a mark of inherited position, this fabric became a disputed medium of style. Second, this commodity sparked recurrent legalisation attempting to preserve societal morals and the secular status quo. ${ }^{35}$ Such enactments, failing to restrain, rather stimulated imitation and innovation. ${ }^{36}$ Silk, initially the stuff of cardinals and kings, became available to the wives and daughters of sugar-bakers, sausagemakers and their ilk. ${ }^{37}$ In 1503, according to one disgruntled Bern chronicler, silks could even be found on the backs of peasants. ${ }^{38}$ It is within the context of these multi-variant influences that we will consider painted and printed Indian cottons. The histories of silk and of cotton are both alike and distinct: both brought extraordinary profits to traders, inspired legislative interventions and launched European industries. However, printed cottons illuminate even more directly the connections between the advent of Asian textiles and the development of fashion in Europe that spanned social ranks.

\section{III.}

Cotton textiles were virtually unknown in most of Europe in the late fifteenth century. ${ }^{39}$ The exception was in the Mediterranean regions, most particularly the eastern Mediterranean, where the trade in Indian printed and painted cottons was centuries old. Surviving examples of painted and printed cottons from Old Cairo (carbon dated from the tenth through the fifteenth centuries) contain a range of common and medium quality goods that arrived in that the region. ${ }^{40}$ Unlike most silks, these fabrics produced in the Gujarat, the north-west of India, were made in the broadest array of qualities and from the outset were directed at a very wide range of customers. In the thirteenth and fourteenth centuries, Venetian merchants eyed the Cairo-based trade in Indian cottons hungrily and worked to become significant intermediaries in a lucrative traffic with Levantine and wider Mediterranean markets. ${ }^{41}$ But with the arrival of the Portuguese in India, about 1500, the established trade routes were challenged, as direct ocean traffic brought Eastern merchandise to Western Europe with profound results.

In Europe, woollens, but also silks and velvets, were patterned on the loom 
and their design was the product of complex methods of weaving and finishing. ${ }^{42}$ Thus the "fashioning" of textiles in Europe had relied mainly on time-consuming techniques of weaving on the loom and embellishing with the needle. In contrast, Indian artisans in the textile regions of the Gujarat, Coromandel Coast and Bengal produced a rainbow of colours, patterns and prints suited to the tastes of discrete markets from Japan to East Africa, Indonesia to Central Asia, Persia and to the Eastern Mediterranean beyond. Painting and printing were more adaptable, faster and less expensive than weaving design. The range of designs intrigued Europeans from the outset. From their arrival in India, generations of Europeans marvelled at the unique qualities of Indian cottons. François Pyrard drew a vivid picture of the products he found in western India, goods produced in Gujarat and that had been shipped westward for centuries, long before his arrival in Gujarat in the seventeenth century:

the principal riches [of this region] consist chiefly of silk and cotton stuffs, wherewith everyone from the Cape of Good Hope to China, man and woman, is clothed from head to foot. These stuffs are worked, and the cotton also made into cloths of the whiteness of snow, and very delicate and fine, and is also woven of a medium and of a thicker stoutness for divers uses. Others are bespangled and painted with various figures. The silk-work is the same of all these kinds, the articles imported being pillows, counterpanes, and coverlets, pinked with much neatness, and cleverly worked ... Then there are quilts stuffed with cotton, painted and patterned exceeding prettily. ${ }^{43}$

John Ovington, during his travels to Surat in 1689, noted that: "In some things the artists of India out-do all the ingenuity of Europe, viz., the painting of chintes or calicoes, which in Europe cannot be paralleled, either in their brightness and life of colour or in their continuance upon the cloth". ${ }^{44}$ Europeans were drawn to the brilliant colours of Indian cottons and the precision of their designs, elements unmatched in any fabric they knew. ${ }^{45}$ Within several years of Portugal's first voyages to the East, printed Indian cottons were being incorporated into clerical garb in Lisbon, while lower quality goods were directed to Atlantic and Levantine markets. ${ }^{46}$ They then moved along well-established commercial routes, brought by Portuguese pedlars, for example, into the Basque lands by the mid sixteenth century and into Antwerp's markets about the same time period, appearing in southern England in the first half of the sixteenth century, valued for reasons of aesthetics and practicality. ${ }^{47}$

Maxine Berg, in her studies of the import of "exotic" products from India, China and Japan in the seventeenth and eighteenth centuries, noticed a European drive towards imitation of imported commodities. The goods themselves with their visual and tactile attributes drew European consumers and that in turn produced attempts to substitute European-made alternatives. (Figure 2) Many of the commodities initially imported from the East were eventually produced at home, partially re-interpreted to suit European tastes and expectations, but rarely relied on the original technologies used to produce them in the East. ${ }^{48}$ Whilst Europeans were keen to appropriate Asia's products, they were unable to acquire the technologies and practical expertise associated with them. Thus the first efforts to adapt Indian floral and botanic motifs took different formsembroidery based on the hybrid motifs displayed on Indian cottons became sta- 
Figure 2

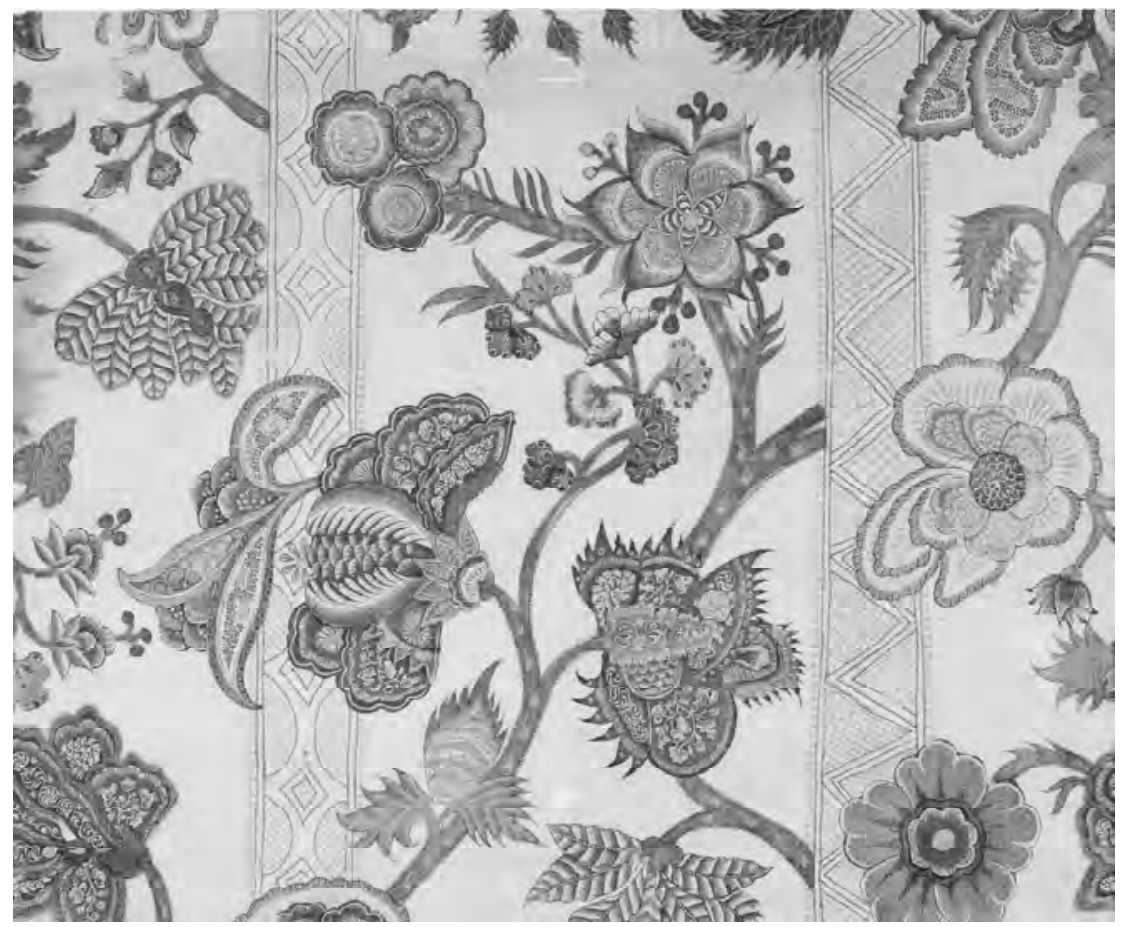

Indian chintz, painted cotton, for the European market. Produced on the Coromandel Coast, c. 1730. Courtesy of the Musée de l'Impression sur l'Etoffe, Mulhouse, 858.141.1.

ples of late sixteenth and seventeenth-century tapestry needlework. ${ }^{49}$ At the same time, European artisans recognized the deficiency in their skills and struggled to replicate the textiles that were increasingly in demand.

The fashion for Indian textiles arose at a time of material and cultural flux in Europe. The fabrics offered abundant visual references to botanic themes during an era of intense preoccupation with flora. They arrived in a wide range of qualities, including cheap, light cottons suited to shirts and handkerchiefs and more refined draperies suitable for hangings and apparel. Acquisition of cottons represented comparatively modest outlays, compared to silks or even to fine linen. Indeed, the nature of the commodity itself sparked desires and encouraged fashion consciousness of various sorts down the social scale. Lipovetsky offers a critique of Gabriel de Tarde's assessment of "the age of fashion" refuting Tarde's claims for the centrality of new foreign materials in this phenomenon. Local preconditions were doubtless important in the advent and articulation of the European fashion system; but there can surely be no doubt that "the prestige of [the] foreign" figured centrally in this history. ${ }^{50}$ Indeed, Georg Simmel theorized that the fashion phenomenon was only to be found in what he termed "higher 
civilizations," where the "foreignness" of objects added to their attraction, rather than detracting. ${ }^{51}$ Calicoes and chintzes provided features unmatched in other fabrics with colours, motifs and practicality that inspired. Whether in cushions, kerchiefs, bed quilts or curtains, by the seventeenth century tastes for this product were well established, growing larger with the sustained marketing by trading companies like the Dutch VOC and the English East India Company. Decorative household textiles were an important early market niche for Indian imports; latter matched by fabrics for apparel. By 1684, for example, the English East India Company's import of textiles averaged between 60-70 per cent of its total trade and amounted to more than one million pieces. ${ }^{52}$ The fashion contagion presented the contentious prospect of a society remade, reordered, reformed. Ironically, even as Asia began to be characterized by some European writers as an unchanging "other" ${ }^{153}$ (the antithesis of fashion), imports from that region and the insatiable appetite for Asian-style textiles reshaped Europe.

By the late seventeenth century, Europe's governments awoke to the threats posed by the mass importation of cottons: the disruption of local textile industries and the social confusions encouraged by this fashion. Injunctions and prohibitions followed with a re-articulation of sumptuary legislation begun centuries before, but now with a more protectionist than social bent. ${ }^{54}$ The history of the calico craze is well known. ${ }^{55}$ Faced with the passion for calicoes so widely entrenched, Europe's artisans sought to copy what they saw flooding into shops and markets. Yet, despite the continuing influx of cottons from Bengal, Gujarat and the Coromandel and despite the careful study of this trade by sojourning Europeans, knowledge of Indian techniques remained partial and sporadic among European artisans before the third quarter of the seventeenth century. Limited direct observation and uncertain engagement with technical texts explains much of this deficit. References by the Portuguese Duarte Barbosa in the early sixteenth century and by the Frenchman François Bernier who travelled to India in 1665 were important conduits of information. ${ }^{56}$ However, by the 1670s the quantities of Asian textiles shipped to Europe had become so substantial that drastic measures to defend the interests of European manufactures were advocated. There was an equally urgent need felt for Europe to produce textiles that could rival the colours and designs of their Asian competitors. If Asian imports provided the initial incentive for product innovation and import substitution, it was clear that Europeans knew too little about colourfast dyes and textile printing to produce immediate results.

Among Europe's businessmen there was however an equally deep-seated determination to match or exceed Indian artisans in decorative skills—skills which, once mastered, could be applied to plain imported cottons or locallymade linens. Close, routine consultation between the East India companies and their factors in India attempted to ensure that the imported textiles met local European standards and tastes. However, Europe's entrepreneurs could see the benefits of developing a printing industry more responsive to local fashion cycles, working within shorter timeframes. In sum, after Indian cottons had launched a more broadly popular pattern of consumption with a malleable commodity suited to elite and plebeian tastes, ${ }^{57}$ European entrepreneurs soon sought to transplant printing, the most fashionable dimension, to European workshops; 
and that promised a more intensive, vibrant relationship between customer and producer, and a new articulation of the fashion dynamic.

IV.

European textile manufacturers had substantial knowledge of dyeing, but they knew little about the printing of textiles. Woollens, but also silks and velvets, were patterned on the loom and their designs were the result of complex methods of weaving and finishing. From the later middle ages rudimentary engraved wooden blocks were used to print simple designs on linens and woollens, but this specialised industry never expanded beyond the Rhenish provinces of Germany. Nor was it able to upgrade its production to high-quality printed textiles. ${ }^{58}$ By

\section{Figure 3}

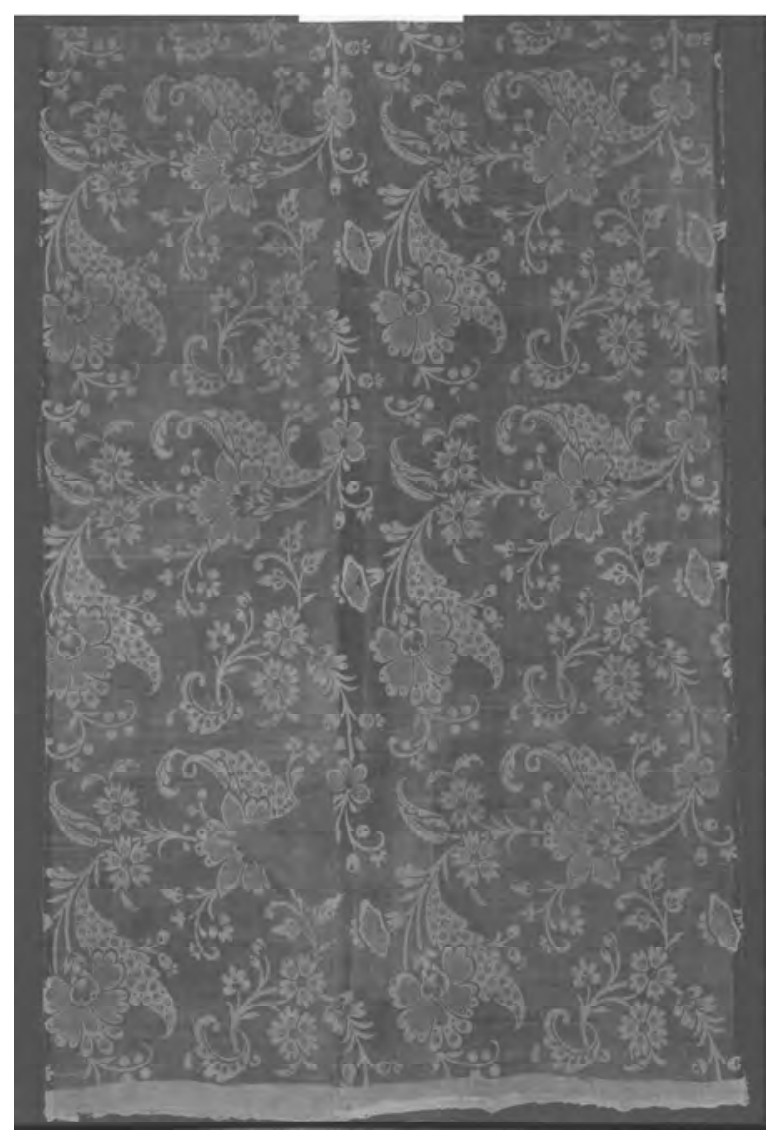

Block-printed furnishing cotton textile. Printed possibly in England or the Netherlands on Indian cloth, c. 1690-1700. Victoria and Albert Museum, T.12A.1884. 
contrast Asia (and India in particular) had developed a variety of processes that can be roughly distinguished into the three broad categories of dyeing, painting and printing. Although textile historians believe that most Indian cottons were painted, ${ }^{59}$ in some areas such as Musulipatam, Nizampatam, Narasapur, Armagaon and Madras both techniques were in use. ${ }^{60}$ In West India and Gujarat most chintzes were printed using wooden blocks and one of the various techniques that included direct printing, bleach printing (bleaching the design on an already dyed cloth), "mordant printing" (printing with mordants and then bleaching the unmordanted areas) or resist printing (printing a viscous substance, followed by dyeing, followed by the cleansing of the substance).

This enormous variety of processes, combined with the local availability of high-quality dyes and the skilled use of mordants made Indian textile production far superior to its European counterpart. ${ }^{61}$ In the sixteenth and seventeenth centuries Europeans attempted to emulate Indian patterns by first painting similar motifs on heavy canvas cloths used for inexpensive household decoration. ${ }^{62}$ The drive to develop a European textile printing industry was clearly in place by the seventeenth century and in 1619 a certain George Wood was granted a 21year patent for the printing and staining of linen cloth in England and Wales. ${ }^{63}$ However inferior the early copies might be, they reflect determined efforts to try to meet the demand for the extraordinary array of cottons so warmly received by European consumers. (Figure 3)

The take-off in textile printing in Europe occurred during the last quarter of the seventeenth century. The imitations of toiles peintes produced since the $1660 \mathrm{~s}$ in Marseilles and shortly thereafter in Dauphiné, Vivarais, Languedoc, Poitou and Normandy were the result of printing coloured designs by means of wooden blocks. ${ }^{64}$ As observed by Olivier Raveux, Marseilles had direct access to Turkish printed cottons, so-called Indiennes, and the Mediterranean city attracted not just abundant quantities of cottons, but also skills and expertise. ${ }^{65}$ Several Armenian workmen proficient in the printing and painting of cotton textiles settled down in Marseilles during the last quarter of the seventeenth century, forming business partnership with local entrepreneurs. ${ }^{66}$ Armenians could also be found in other parts of Europe, acting as conveyors of previously unknown techniques. ${ }^{67}$ In Amsterdam, in the 1670s, several Armenians were employed to "draw and colour or dye all kinds of East Indian cottons, which has never before in this country been practiced" ${ }^{68}$ The calico printing industry quickly developed in several centres of the Netherlands and in particular on the outskirts of Amsterdam. By the 1740 s there were more than 100 textile print shops in Holland, 80 of which were in Amsterdam. ${ }^{69}$

Dutch entrepreneurs moved also to Alsace and the Franco-Swiss border to found important calico printing centres such as Basel, Mulhouse and Neuchâtel. ${ }^{70}$ In the late 1750 s the Fabrique-Neuve near Neuchâtel in Switzerland had developed to become one of the largest eighteenth-century "proto-factories" in Europe, employing more than 300 workers. ${ }^{71}$ In England, William Sherwin of West Ham near London took out a patent in 1676 "for invention of a new and speedy way for producing broad calico, which being the only true way of the East India printing and stayning such kind of goods". ${ }^{72}$ After Sherwin's patent expired in 1691, several print-works opened in and around London. ${ }^{73}$ There is no evidence for the presence of Armenians workmen in England. It is more 
likely that the industry developed thanks to the expertise and knowledge of those who had worked in similar undertakings in the Netherlands, especially French Huguenots who had fled France after 1685 and had spent some years in Amsterdam and other Dutch cities before reaching London. ${ }^{74}$

It is no coincidence that England and Holland were the earliest centres of experimentation in calico printing. By the last quarter of the seventeenth century both nations imported Indian cotton textiles more than any other European country. ${ }^{75}$ Buoyant domestic markets for printed, vibrant, washable textiles were at the heart of attempts to imitate and substitute imported Indian cotton with home-produced wares. However, results were not immediate. It took several decades from these early starts for the continent to develop a calico printing industry that could rival in quality its Indian counterpart. Until the 1730s, what Europe could produce were printed textiles of inferior quality that could not match the complex and fashionable designs of Indian calicoes. Among other deficiencies, Europeans had to overcome their inability to produce long-lasting colours. ${ }^{76}$ High-quality petit teints (colours that faded with light and washing) were produced; but European artisans were unable to produce grand teints (permanent colours resistant to light and wear).

Economic historians have suggested that the development of the European calico printing industry was facilitated by the enactment of protectionist measures. ${ }^{77}$ High duties on imported Indian silks and cottons were followed by total bans. These measures were applied in several European countries, first in France in 1689 and later in England (1701 and a total ban in 1721), and Spain (1713) among many. ${ }^{78}$ The period of "Mercantilist protectionism" stretching from the end of the seventeenth to the general repeal of bans in the third quarter of the eighteenth century, coincided with the geographic spread and technological improvement of calico printing in Europe. The only nation to be a staunch defender of free trade was the Dutch Republic where restrictions on import, manufacturing or the wearing of printed cottons were never enacted. Holland remained an important manufacturing centre and probably an illegal supplier of printed cotton textiles to the rest of Europe, but the progress of the industry there was not as intense as in the late seventeenth century. At the opposite end of the spectrum, between 1689 and 1759, France forbade not just the import but also the manufacture of printed cottons in most of its territory. The only places to escape this restrictive imposition were those cities and small regions outside the direct administration of the central government, such as Marseilles, but also the Arsenal in Paris, Angers, Rouen, Nantes and Orange where the industry developed in the 1740s and 1750s. ${ }^{79}$ In Orange, Rodolphe Wetter-who was also the owner of an "English blue" calico print shop in Marseilles— set up in 1744 one of the most celebrated print works in Europe (Figures 4).

The industry spread also to other European cities. In the 1760s there were more than 12,000 calico printers in Spain. Barcelona, where Estaban Canals had founded the first print work in 1738, was one of the major centres of production in Europe.$^{80}$ In 1760-a year after the repeal of the ban in France- the Swiss Oberkampf opened his celebrated business in Jouy-en-Jossa, seeing the potential to supply the vast French market through production in situ. Central Europe enjoyed similar developments. The textile printing trade began in 
Figure 4

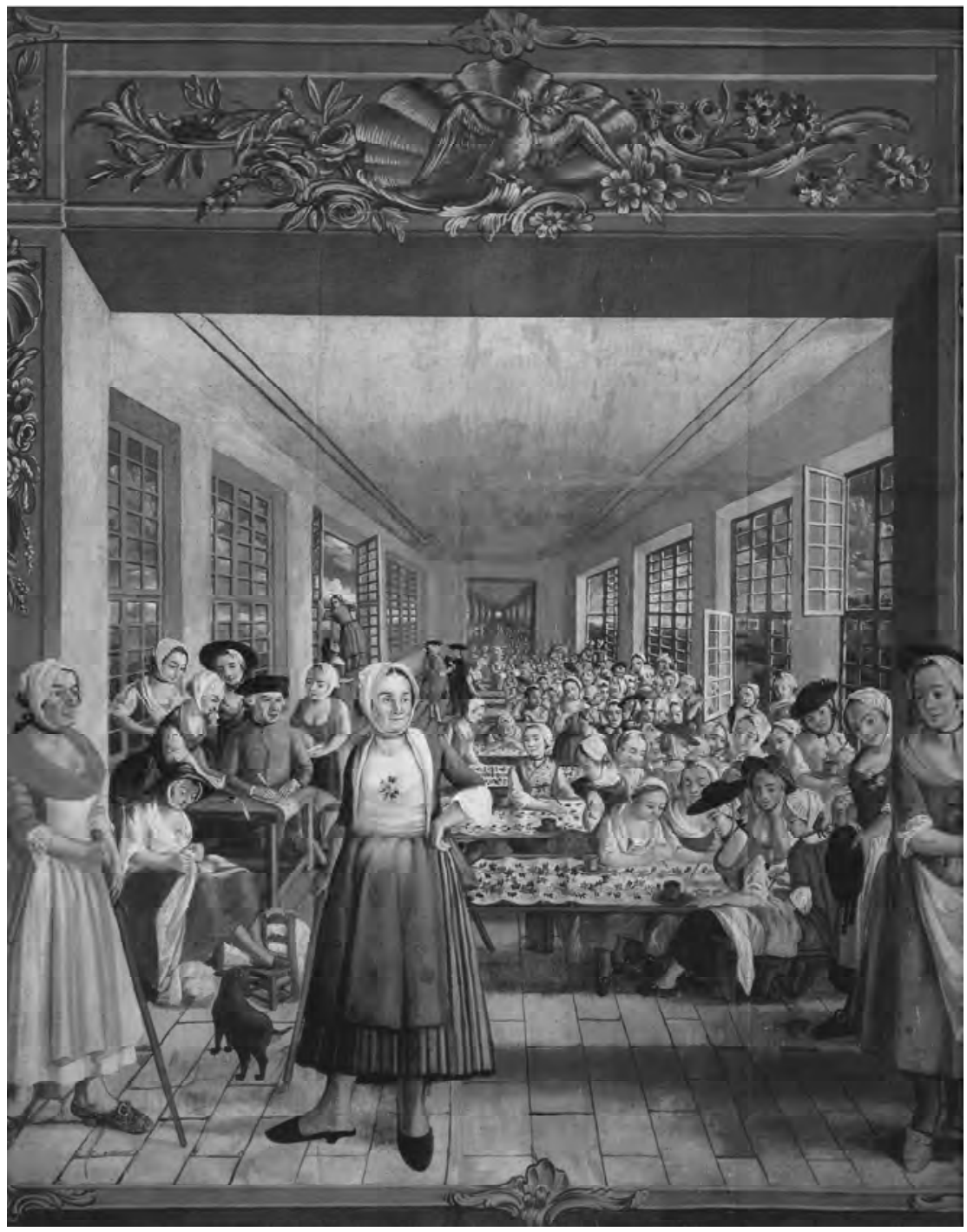

Joseph Gabriel Maria Rossetti, The paintresses' room at the Wetter printworks in Orange, France, 1764. Musée Municipal d'Orange. 
Prague from 1767 and twenty years later 12 firms employed more than 1,000 men with 314 printing tables. ${ }^{81}$ By the late eighteenth century calico printing had reached enormous size not only in Britain and France, but throughout the rest of Europe. At the same time, there was continuing competition from Indian artisans, who, in conjunction with the East India companies, offered Europe an ever wider array of patterned fabrics to meet the shifting tastes of consumers. In many instances, attribution of textiles to a European or Indian point of origin became increasingly difficult - a fact that worked to the advantage of European printers.

\section{V.}

European producers were setting new standards as they had direct access to consumers and could quickly assess their preferences, however varied. ${ }^{82} \mathrm{With}$ print works in closer proximity to western markets the yearly and seasonal variations in styles could be captured or encouraged by timely interaction with consumers. In this respect, the East India Company's access to the "original" product did not necessarily mean a competitive advantage beyond the price differential with European-printed cottons. Once European calico producers perfected their techniques at a sufficient level to satisfy popular markets, the copy could become more appealing than the original. It is in this light that we should read the continuous concern of the East India companies to supply products that could sell well and swiftly. And their worries were not just about the latest colour or European consumers' preferences for lighter shades. "The floweres must run through the whole piece from end to end," reported one dispatch from London to India, "whereas, the Flowers have of late been observed to have been begun at each end of the piece, insomuch that in the middle they have, instead of agreeing, been opposite to one another". ${ }^{83}$ A language of precision and exactitude in following specifications was paramount not only in the productive process but also in the final product: "[calicoes] must be either 13 or 15 yards on a fine calico. Half of fine bunches of four colours, viz., the ground work drawing black, filled up with red and peach blossom colour and the twigs or spring green." ${ }^{\prime 4}$

The deep blue indigo-dyed cotton textiles had captivated European merchants and travellers in seventeenth-century India, especially when blended with striking designs in red, green and yellow. These were produced through a resist dyeing process based on the waxing of the areas to remain undyed. This labour-intensive procedure allowed artisans to produce mostly "white on blue" rather than "blue on white" that would have meant the waxing of most of the cloth. ${ }^{85}$ During the last quarter of the seventeenth century Europeans adopted not only the product but also the process of production with waxing and a process of tepid indigo fermentation. However, by the early eighteenth century they were already experimenting with improved techniques, unknown in Asia. The most important of these was the use of cold vats obtained by dissolving indigo in iron sulphate. This process, invented in England in 1734, quickly replaced the hot fermentation of indigo that damaged the reserve (those parts that had not to be dyed and were covered in wax). ${ }^{86}$

In addition to important new techniques, Europeans most differentiated themselves from Indian manufacturers in the use of mechanical devices. As al- 
Figure 5

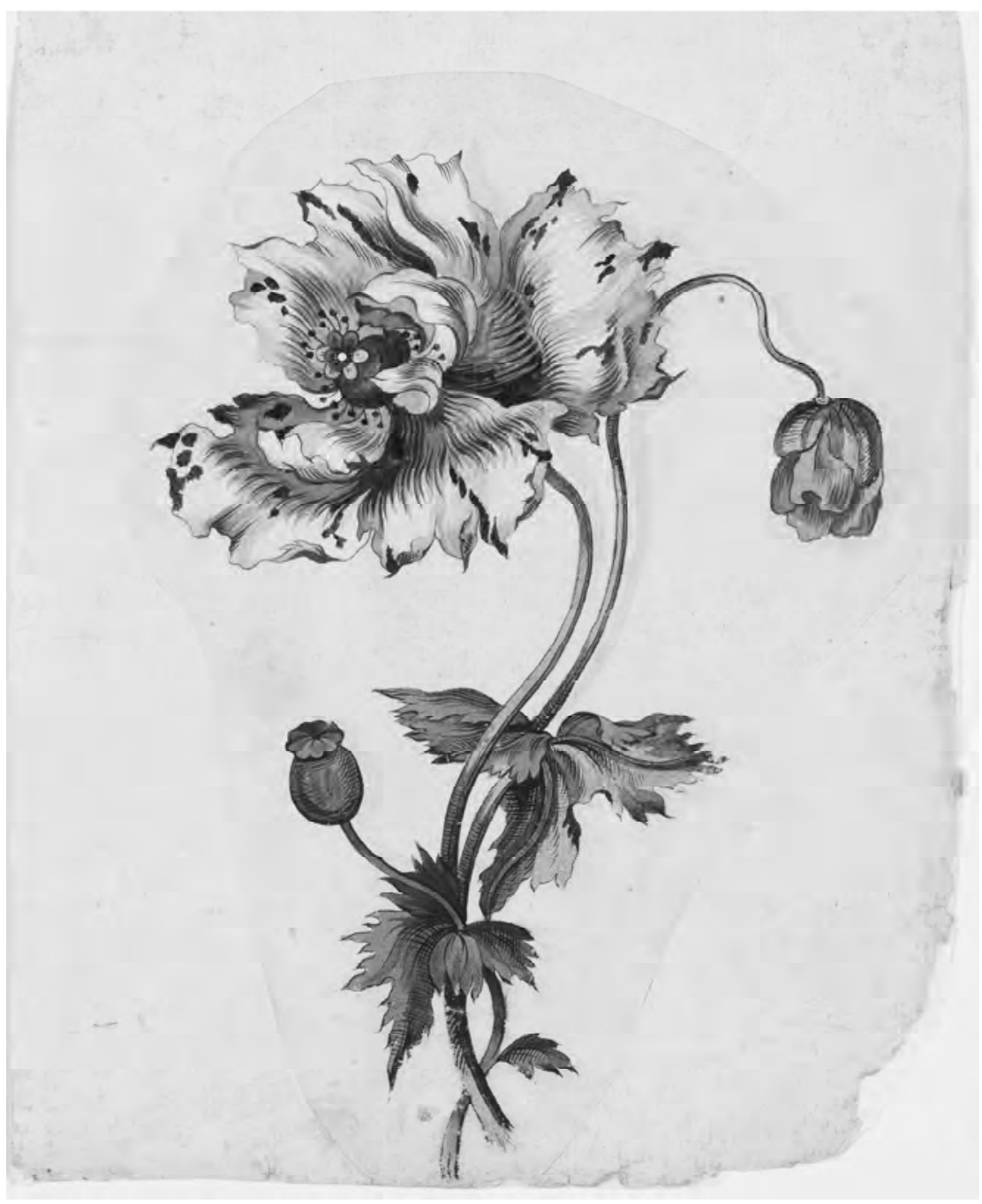

Peonies. Design on paper with gouache, Manufacture Haussmann, Logelbach near Colmar, c. 1780. Courtesy of the Musée de l'Impression sur l'Etoffe, Mulhouse, S.314.1. 
Figure 6

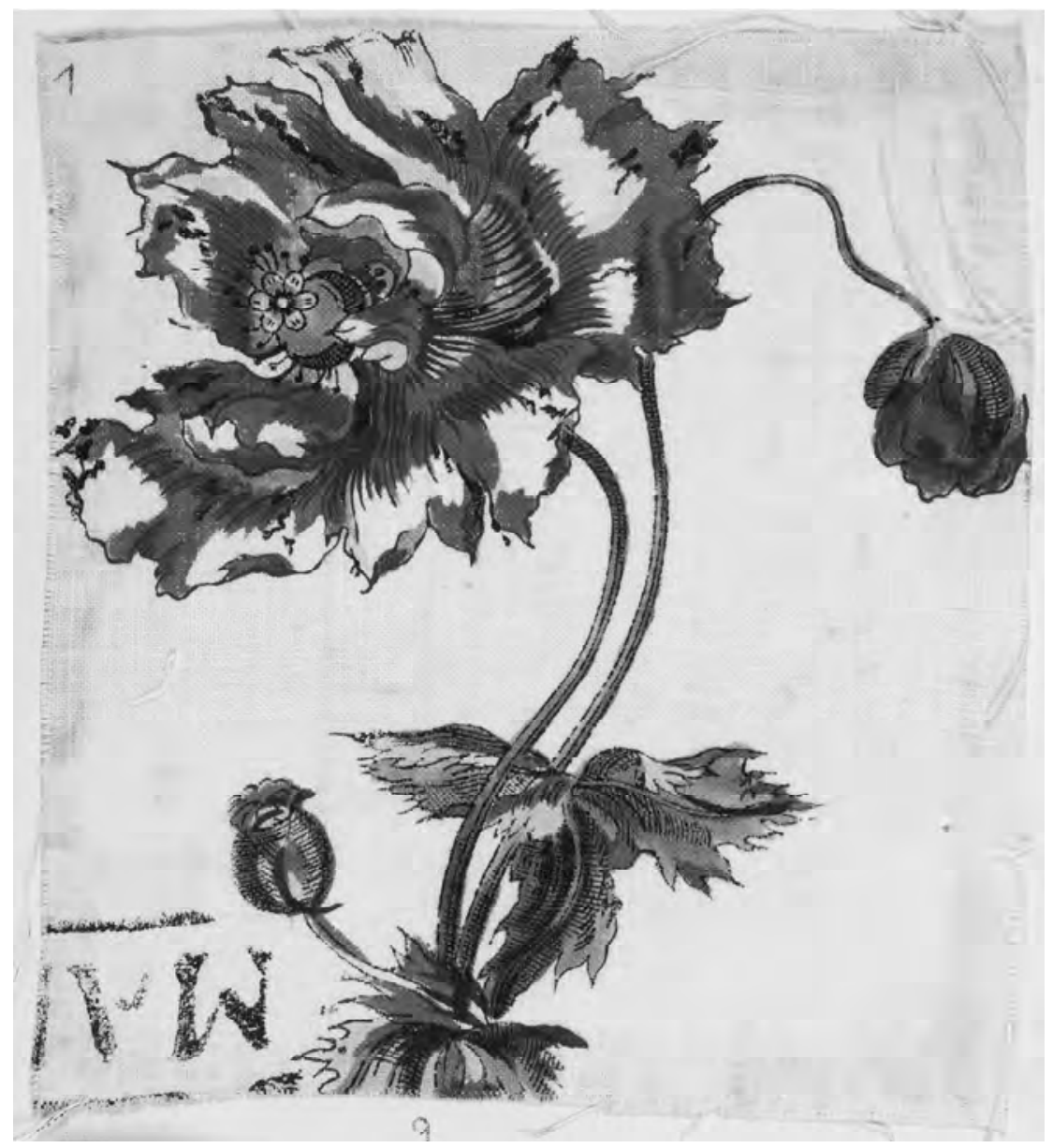

Peonies flower, block printed on cotton, Manufacture Haussmann, Logelbach near Colmar, c. 1780. Courtesy of the Musée de l'Impression sur l'Etoffe, Mulhouse, S.314.1.

ready observed, of all the possible ways of "fashioning" textiles, Europeans had concentrated in particular on weaving and embroidery. Until the late seventeenth century their knowledge of dyes was very limited, and non-existent for reserve dyeing. Painting, another major Indian tradition in cotton textiles, was never seen as a possible avenue for Europeans, as it was very labour intensive. ${ }^{87}$ Printing was, however, a much simpler activity based on the engraving of a wooden block and the subsequent impression of the colour or mordant on the textile. Multi-coloured calicoes required a process in several stages with subsequent impressions on the same cloth. ${ }^{88}$ Europe's reliance on printing rather 
than painting, made it paramount to find a process that was not only faster but that could also produce better-quality textiles. Book printing and engraving had reached new heights in the early eighteenth century and techniques had been perfected to reproduce paintings in the form of etchings and popular prints. The rough and unsophisticated visual appearance of woodcut prints found in seventeenth-century ballads and sonnets, contrast with the polished and accomplished prints of the mid-eighteenth century such as Hogarth's famous series. Printing on textiles underwent a major series of technical changes in the second half of the eighteenth century, all of which were closely tied to the technology and artistic production on paper (Figures 5 and 6). ${ }^{89}$

The first innovation was the use of copper plates, instead of the traditional wooden blocks, first devised by Francis Nixon of Drumcondra near Dublin in $1754 .^{90}$ The use of copper plates was not just a process innovation. Its main aim was to improve the quality of the product. It allowed the precise replication on textiles of complex designs and, more commonly, of scenes from fables, representations of the countryside, commemorative battles and the like. The visual "language" of cotton textiles dramatically changed thanks to the use of copper plates (Figure 7). The process was quickly adopted throughout Europe, first in England, and later in France, Germany and Switzerland. Oberkampf was a relatively late comer to the trade, seeing the process of calico printing performed with copper plates in London in 1773 for the first time; yet, in just a few years, he became the best known producer of toiles in Europe. ${ }^{91}$ As Chapman and Chassagne observe:

Oberkampf's goods acquired a social cachet as his customers were obviously the most distinguished and influential people, notably the Duke of Gontaud (Lauzun) who boasted in the salon of the Duchess of Choiseul in 1776 of having given Oberkampf an oriental design to copy, and that when he succeeded in reproducing it exactly he [the Duke] had pretended the copy was a genuine Indian one and the court believed him. ${ }^{92}$

Successes in technology and in marketing enabled Europe's calico printers to be attentive to the nuances of a fashion system now well out of its infancy, where the variations in taste that arose by region, social rank and season were carefully addressed. This became the source of the printers' prosperity. ${ }^{93}$

The second important innovation in cotton printing was the invention of the rotary printing machine patented by the Scot Thomas Bell in 1783. Attempts to perfect a printing machine had started at the very beginning of the century when a wooden printing roller was used (Figure 8). In a similar vein, Keen and Platt invented a three-colour roller in $1743 .{ }^{94}$ The real leap came, however, only in 1783 when Bell (who worked at Livesey, Hargreaves Hall and Company in Preston, England) patented a method of printing from engraved cylinders. Two years later he was printing in six colours. ${ }^{95}$ Roller printing must have appeared revolutionary compared with Indian painting if we consider that it took an Indian craftsman two weeks to paint a calico seven metres long. ${ }^{96}$ But the gap between Indian and European production was not just the result of different levels of productivity. Both copper plates and rotary printing made the productive processes extremely capital intensive. European producers could 
Figure 7

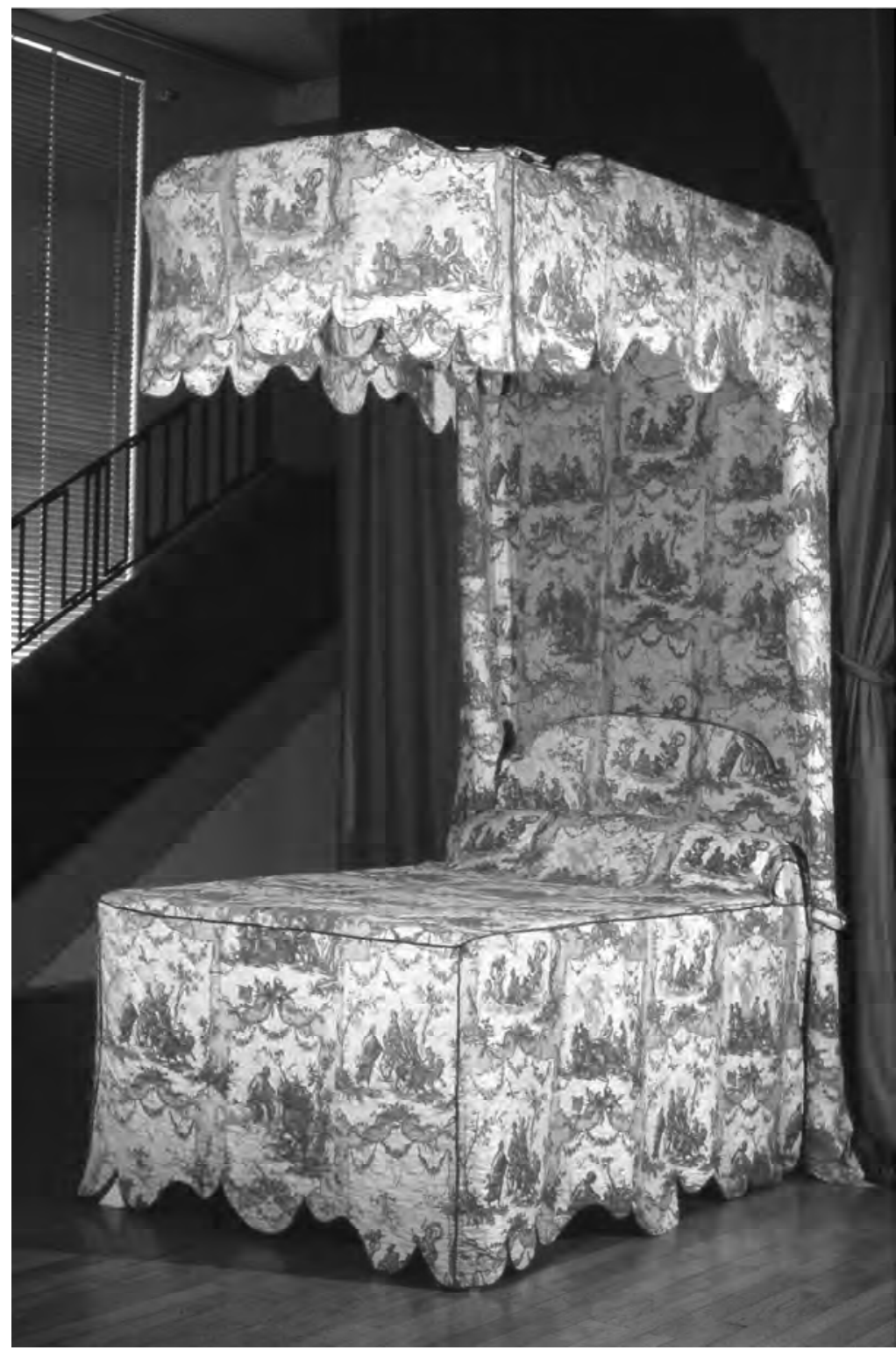

Copperplates revolutionised the vocabulary of cotton textiles in Europe. Lit à la Duchesse, copper-printed cotton, 1783-89. Produced by Oberkamft at Jouy-en-Josas. Courtesy of the Musée de l'Impression sur l'Etoffe, Mulhouse, 984.27. 
Figure 8

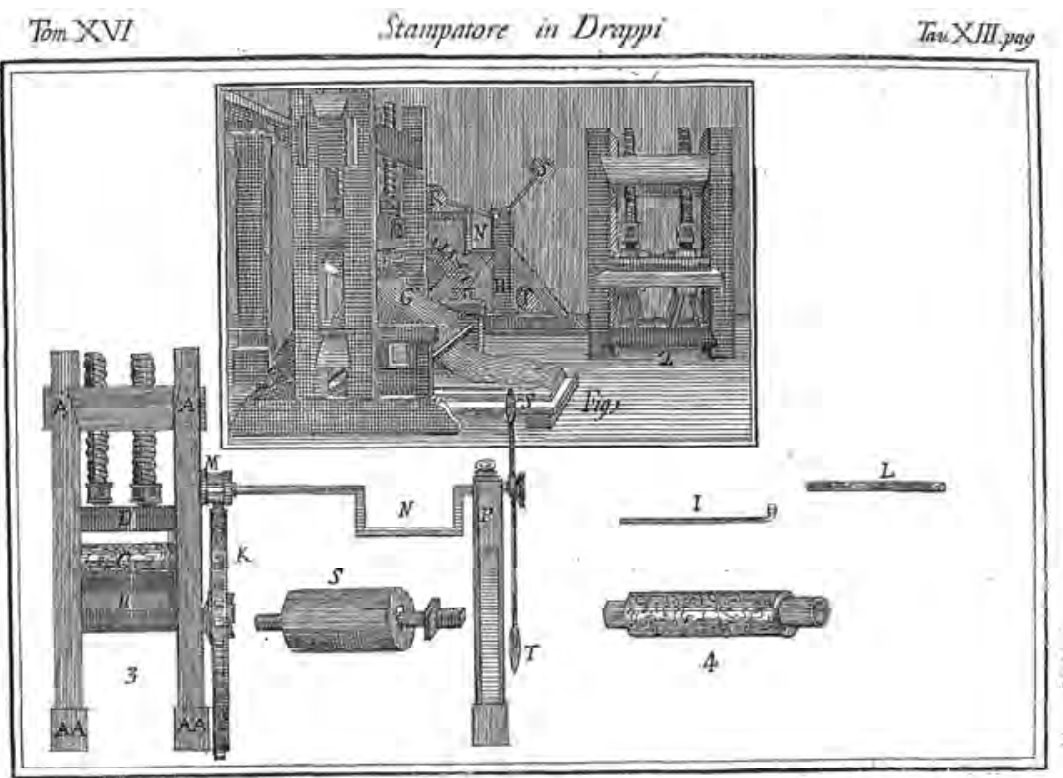

"Stampatore in Drappi" (printing cloth) in Dizionario delle Arti e de' Mestieri, by Francesco Griselini, Venice 1768-78, vol. 16, Tavola XIII.

only expect to generate a profit from large runs with the identical designs, as the cutting of a roller cost in the region of $£ 7$. The cycle of fashion accelerated in the process.

VI.

Printing fashion - on cloth - was a milestone in the development of a responsive, consumer oriented manufacturing sector in Europe. The debt to Asia, to India, was considerable and was rooted in the impact of Asian textiles on the economies, societies and sensibilities of Europeans over centuries. The processes of printing on textiles, as much as the transmission of design idioms through printing, were profoundly important communicative acts. Over the centuries of trade in printed cottons across Eurasia, when the majority of the world's populations were illiterate, communication took many forms other than through texts. Printed Indian cottons were among the most egalitarian of commodities, in cost, in quality and, following direct trade between Europe and Asia, in availability. The ordering of space, the transmission of botanic imagery, and the varied arrangements of colours represented a rich repository of visual information on the surface of these fabrics. ${ }^{97}$

For millennia, imagery devised and treasured in one region of the world per- 
colated along trade routes, carrying on a measured visual exchange as peoples responded to the iconographic stimuli and the idioms themselves evolved. Bringing printed cottons to Europe, traders facilitated a new type of visual dialogue involving both the leisured elite and the labouring classes with the Indian producers of printed cloth. Literate Europeans have left a record of the impact of these goods, expressing, as did John Huyghen van Linschoten, their wonder at the "excellent faire linnen of Cotton made in Negapatan, Saint Thomas, and Masulepatan, of all colours, and woven with divers sorts of loome workes and figures, verie fine and cunningly wrought." ${ }^{98}$ Yet, we have a more difficult task determining the full cultural reception of printed textiles among the mass of Europeans, "literate" in symbolic and iconographic idioms, but unlettered in the written word. At the same time as books of all sorts were becoming more common, a non-literate print media carried uniquely stylized or densely rich imagery into new markets, to be judged and assessed by a population skilled in visual translation. We know the aggregate outcome of this encounter, even if not the detail responses from each community, as peoples from Friesland to Portugal, Catalonia to Scotland, adopted and interpreted prints from India into their lives, their homes and their apparel. ${ }^{99}$

The use of printing techniques to transmit this visual information enabled replication at an affordable price. Textiles were perhaps the most ubiquitous medium, but prior to the appearance of Indian printed cottons decorative patterning in textiles was the preserve of Europe's wealthiest alone. An aesthetic previously restricted, thereafter gradually became commonplace, absorbed into cultures, modified and reframed within the receiving community. Printing on cotton (an Indian device) enabled this significant cultural exchange and printed designs on an affordable medium intensified the fashion ethos among disparate European populations. Communication in this context shaped the culture of Europe and presented an important new medium through which to transmit imageladen materials to the widest possible audience. Jack Goody observes that:

Culture, after all, is a series of communicative acts, and differences in the mode of communication are often as important as differences in the mode of production, for they involve developments in the storing, analysis, and creation of human knowledge, as well as the relationships between the individuals involved. ${ }^{100}$

Two areas of Eurasia, Western Europe and the Indian subcontinent, possessed substantially different bodies of knowledge in the seventeenth century. What seemed also to be different was how this knowledge was shared, moved, applied, confirmed or disproved. ${ }^{101}$ In this process, the discovery and application of new printing techniques was vital to the advance of the European trade. But, printing's role was also multifarious, for printing also played a key role in the diffusion of fashion information in written and visual printed form. By 1600, needlework booklets with printed designs, some showing Asian influence, were being sold in various parts of Europe. ${ }^{102}$ Printed paper patterns were followed through the seventeenth and eighteenth century by printed announcements of cargoes, newspaper advertisements of retails stock and seasonal discussions of dress styles, as well as magazines with instructions, patterns and images of new designs. 
The circulation of printed information on style was not exclusive to Europe, as Craig Clunas has shown for the late Ming period. ${ }^{103}$ However, the capacity to offer seasonal and mid-season novelties in printed fabrics, designed for plebeian and elite buyers, marked a momentous advance for European printers. Alan Hunt defines fashion as "a process ... in which both producers and consumers place some conscious valuation on change." 104 Change was a phenomenon known and valued by later eighteenth-century suppliers who brought "loads of prints on three mornings a week-Tuesday, Thursdays, and Saturdaysfrom the works. [ ... ] A crowd of drapers was generally waiting for the doors to be opened, when they would rush upstairs to the saleroom, and a scramble for prints would ensue." ${ }^{105}$ Europe excelled through the application of new technologies; but they built their success on the cultural and economic structural changes propelled by centuries of imported Asian textiles. Asian fabrics had a profound impact on European design, material culture and production and the changes engendered through these imports included the constancy of change that challenged hierarchy and the profits from change that revised society. The characteristics of materials like Indian cotton established a template for manufactures that would appeal to "the many poorer sorts" as well as the "gallants". ${ }^{106}$ The renewal of dress and furnishings, along with the desire for change, stood at the heart of fashion; Indian manufactures sparked the desire and their cottons provided the material to assuage this craving. Europe learned from this example and the fashion dynamic was strengthened as a consequence.

Department of History $\mathbb{E}$ Classics

Edmonton AB T6G 2H4

Canada

Department of History

Global History and Culture Centre

Coventry CV4 7AL

United Kingdom

\section{ENDNOTES}

The authors would like to thank Ulrich Lehmann and Patrick O'Brien for their comments. Our thanks also to the LSE Global Economic History Network, the University of Alberta, the Social Science \& Humanities Research Council of Canada, the Musée de l'Impression sur l'Etoffe, Mulhouse, and in particular its curator Jacqueline Jacqué, Dilys Blum of the Philadelphia Museum of Art, Linda Eaton of Winterthur, Alex Palmer of the Royal Ontario Museum, and Rosemary Crill and Clare Browne of the Victoria \& Albert Museum for assisting the research for this article.

1. C.A. Foley, "Fashion," Economic Journal 3, no. 11 (1893), p. 460.

2. See, for example, Janet Abu-Lughod, Before European Hegemony: the World System, A. D. 1250-1350 (New York, 1989); and Andre Gunder Frank, ReOrient: Global Economy in the Asian Age (Berkeley, 1998). 
3. John R. McNeill and William H. McNeill, The Human Web: A Bird's-eye View of World History (New York, 2003), p. 3.

4. Giles Lipovetsky, The Empire of Fashion: Dressing Modern Democracy, trans. by Catherine Porter (Princeton, 1994), p. 15. Fernand Braudel, for instance, contrasted what he claimed was mobility in European fashion with unchanging Chinese styles, and also Ottoman and Arab sartorial immobility. Fernand Braudel, Capitalism and Material Life, 1400-1800, trans. by Miriam Kochen (London, 1973).

5. Craig Clunas, Superfluous Things: Material Culture and Social Status in Early Modern China (Cambridge, 1991); Timothy Brook, The Confusions of Pleasure: Commerce and Culture in Ming China (Berkeley, 1998).

6. For a discussion of the interactions between an advanced Asia and a backward Europe see: Lynda Shaffer, "Southernization," Journal of World History, 5, no. 1 (1994): pp. 1-22. See also Maxine Berg's several articles on the subject: "Manufacturing the Orient. Asian Commodities and European Industry 1500-1800," in Simona Cavaciocchi, ed., Prodotti e Tecniche d"Oltremare nelle Economie Europee. Secc. XIII-XVIII. Atti della 'Ventinovesima Settimana di Studi', 14-19 Aprile 1997 (Florence, 1998), pp. 385-419, and Maxine Berg, "Asian Luxuries and the Making of the European Consumer Revolution," in Maxine Berg and Elizabeth Eger, eds., Luxury in the Eighteenth Century: Debates, Desires and Delectable Goods (London, 2003): pp. 228-244.

7. Maxine Berg, "In Pursuit of Luxury: Global History and British Consumer Goods in the Eighteenth Century," Past and Present 182 (2004): pp. 85-142.

8. Abu-Lughod, Before European Hegemony, p. 13. The phrase was coined by Richard Haëpke and also adopted by Fernand Braudel.

9. Sarah-Grace Heller, "Fashion in French Crusade Literature: Desiring Infidel Textiles," in Désirée G. Koslin and Janet E. Snyder, eds., Encountering Medieval Textiles and Dress (New York, 2002), p. 109. For reflections on the expansion of fashions, even through the economic crises of the fourteenth century, see Lipovetsky, Empire of Fashion, pp. 20-21, 38-41.

10. This paper does not employ Barthes's semiotic definition of a "fashion system", based as it was in a twentieth century system replete with the imagery and texts of a robust fashion press, functioning in conjunction with production and display. Roland Barthes, The Fashion System, trans. by Matthew Ward and Richard Howard (New York, 1983). In contrast, we intend to identify and analyse the early appearance and function of fashion as a self-perpetuating process which informed the historical dynamic, linking itself with other components of the society and economy. The "systemic" nature of fashion thus rested in its interactive relationship with historical change.

11. For a different perspective on the genesis of the male fashionable figure see, Odile Blanc, "From Battlefield to Court: The Invention of Fashion in the Fourteenth Century," in Koslin and Snyder, eds., Encountering Medieval Textiles, pp. 157-72, and Odile Blanc, Parades et Parures. L"Invention du Corps de Mode à la Fin du Moyen Age (Paris, 1997).

12. Carolyn Sargentson notes, for example, that the trade of the mercer was formally established in Paris in 1268, one of their principal goods being silks and "object de provenance orientale". Carolyn Sargentson, "The Manufacture and Marketing of Luxury Goods: the Marchands Merciers of late 17th- and 18th-Century Paris," in Robert Fox and 
Anthony Turner, eds., Luxury Trades and Consumerism in Ancien Régime Paris (Aldershot, 1998), p. 100.

13. Anna Muthesius, "Silk in the Medieval World," in David Jenkins, ed., The Cambridge History of Western Textiles (Cambridge, 2003), vol. 1, pp. 326, 332-3.

14. Catherine Kovesi Killerby, Sumptuary Law in Italy, 1200-1500 (Oxford, 2002), p. 30.

15. Jerry Brotton, The Renaissance Bazaar from the Silk Road to Michelangelo (Oxford, 2002), pp. 124-52. See also Salvatore Ciriacono, "Les manufactures de luxe à Venise: contraintes géographiques, goût méditerranéen et compétition internationale (XIVeXVIe, siecle)" Crédit Communal_Collection Histoire, 8, no. 96 (1996), pp. 235-51.

16. Giulia Calvi, "Le Leggi Suntuarie e la Storia Sociale," in Maria Giuseppina Muzzarelli and Antonella Campanini, eds., Disciplinare il Lusso. La Legislazione Suntuaria in Italia e in Europa tra Medioevo ed Età Moderna (Rome, 2003), p. 218; Blanc, "Battlefield to Court," pp. 158-59.

17. Kovesi Killerby, Sumptuary Law, 46-7. Kent Roberts Greenfield, Sumptuary Law in Nürmberg: A Study in Paternal Government (Baltimore, 1918), pp. 118-21. See, for example, Lettres patentes de declaration du roy, pour la reformation $d u$ luxe des habits $\mathbb{E}$ reglement d'iceux (Rouen, 1634), pp. 3-5.

18. As Negley Harte acutely observes: "silk did not slip into the minds of Europeans as easily as it did on their bodies." Negley B. Harte, "Silk and Sumptuary Legislation in England," in Simona Cavaciocchi, ed., La Seta in Europa, Sec. XIII-XX. Atti della 'Ventiquattresima Settimana di Studi' , 4-9 maggio 1992 (Florence, 1993), p. 801.

19. Muthesius, "Silk in the Medieval World," p. 325; S. A. M. Adshead, Material Culture in Europe and China, 1400-1800 (Basingstoke, 1997), pp. 81-2; Désirée G. Koslin, "Value-Added Stuffs and Shifts in Meaning: An Overview and Case Study of Medieval Textile Paradigms," in Koslin and Snyder, eds., Encountering Medieval Textiles, pp. 23740. See also A. P. Novosel'tsev, "Oriental Silk Trade with Europe in the Middle Ages," in Cavaciocchi, ed., La Seta, pp. 756-8 and J. Kieniewicz, "Silk Road, Silk Dress and Silk Way of Life. Between Oriental Trade and Western Culture," in ibid., pp. 901-8.

20. Kovesi Killerby, Sumptuary Law, p. 22; Liu Xinru, "Silks and Religions in Eurasia, c. A.D. 600-1200," Journal of World History, 6, no. 1 (1995): pp. 25-48.

21. Kovesi Killerby, Sumptuary Law, pp. 38-9.

22. See, for example, the catalogue based on the exhibition at the Victoria and Albert Museum, London: Marta Ajmar-Wollheim and Flora Dennis, eds., At Home in Renaissance Italy: Art and Life in the Italian House 1400-1600 (London, 2006).

23. Kovesi Killerby, Sumptuary Law, p. 39; John Martin Vincent, Costume and Conduct in the Laws of Basel, Bern and Zurich 1370-1800 (Baltimore, 1935), p. 21.

24. Alan Hunt, Governance of the Consuming Passions: A History of Sumptuary Law (Basingstoke, 1996), p. 46. 
25. Kovesi Killerby, Sumptuary Law, pp. 30, 38-39; Hunt, Governance of the Consuming Passions, pp. 29-33, 47; Herman Freudenberger, "Fashion, Sumptuary Laws, and Business," Business History Review, 37, no. 1/2 (1963), p. 38.

26. Greenfield, Sumptuary Law in Nürmberg, pp. 111, 116.

27. Frances Elizabeth Baldwin, Sumptuary Legislation and Personal Regulation in England (Baltimore, 1926), pp. 157-64.

28. Lipovetsky, The Empire of Fashion, p. 30.

29. Lisa Jardine, Worldly Goods: A New History of the Renaissance (Basingstoke, 1996), p. 69.

30. Luca Molà, The Silk Industry of Renaissance Venice (Baltimore, 2000); Francesco Battistini, L'Industria della Seta in Italia nell'Età Moderna (Bologna, 2003), 1-19; Muthesius, "Silk in the Medieval World"; Joan Thirsk, Alternative Agriculture: A History from the Black Death to the Present Day (Oxford, 1997) pp. 118-29; Linda Levy Peck, Consuming Splendor: Society and Culture in Seventeenth-Century England (Cambridge, 2005) pp. 73-4, 107-110.

31. As Maria Giuseppina Muzzarelli observes for fifteenth-century Italy: "It was the knowledge and evocation of new worlds such as the East that influenced fashion." Maria Giuseppina Muzzarelli, "Nuovo, Moderno e Moda tra Medioevo e Rinascimento," in Eugenia Paulicelli, ed., Moda e Moderno dal Medioevo al Rinascimento (Rome, 2006), p. 37.

32. Kovesi Killerby, Sumptuary Law, 38; Vincent, Costume and Conduct, pp. 44-48, 2116; Baldwin, Sumptuary Legislation, pp. 35-93.

33. Vincent, Costume and Conduct, pp. 45 and 125.

34. A Proclamation, Anent the Sumptuary Act, 1684 (Edinburgh, 1684).

35. See, for example, the various attempts in Tudor England that had little success. The Brief Content of Certayne Actes of Parliament against the Inordinate Use of Apparell (London, 1559).

36. On the imitation of design see Agnes Geijer, A History of Textile Art (London, 1979), pp. 141-55.

37. Vincent, Costume and Conduct, 114-116. See also Natalie Rothstein, "Silk in the Early Modern Period, c. 1500-1780," in Jenkins, ed., Cambridge History of Western Textiles, vol. 1, p. 529.

38. Vincent, Costume and Conduct, p. 48.

39. Europe had developed since the twelfth century a dynamic fustian (mixed linen and cotton) industry in Central and North Italy and parts of Spain, and later in the thirteenth century in Southern Germany and Switzerland. However, this production was confined to coarse bleached fabrics. Maureen Fennell Mazzaoui, "The Cotton Industry of Northern Italy in the Late Middle Ages: 1150-1450," Journal of Economic History, 32, no. 1 (1972): pp. 262-86; Maureen Fennell Mazzaoui, The Italian Cotton Industry in the Later Middle Ages 1100-1600 (Cambridge, 1981); H. Wescher, "The Beginning of the Cotton Industry in Europe," Ciba Review, 64 (1948): pp. 2328-33; H. Wescher, "Fustian 
Weaving in South Germany from the Fourteenth to the Sixteenth Century," Ciba Review, 64 (1948): pp. 2339-50.

40. Ruth Barnes, "Indian Trade Cloth in Egypt: the Newberry Collection," in Textiles in Trade (Washington, 1990), pp. 178-191; Ruth Barnes, Indian Block-Printed Textiles in Egypt. The Newberry Collection in the Ashmolean Museum, Oxford (Oxford, 1997).

41. Abu-Lughod, Before European Hegemony, pp. 239-41; Eliyahu Ashtor, "The Venetian Cotton Trade in the Later Middle Ages," Studi Medievali 17, no. 3 (1976): pp. 675715; Eliyahu Ashtor, Studies on the Levantine Trade in the Middle Ages (London, 1978).

42. Donald King, "Textiles and the Origin of Printing in Europe," Pantheon 20 (1962), p. 29.

43. The Voyage of François Pyrard of Laval to the East Indies, the Maldives, the Moluccas and Brazil, translated into English from the Third French Edition of 1619, edited by Albert Gray (London, 1888), vol. 2.i, p. 246.

44. John Ovington, A Voyage to Surat in the Year 1689, edited by Hugh George Rawlingson (London, 1929), p. 167.

45. See for instance the description by Bernier of the palampores of the King of Aurangzeb representing large vases of flowers. Francois Bernier, Travels in the Mogul Empire A.D. 1656-1668 (London, 1916). See also: George Percival Baker, Calico Printing and Painting in the East Indies in the XVIIth and XVIIIth Centuries (London, 1921), p. 6; Margherita Bellezza Rosina, "Tra Oriente e Occidente," in Marzia Cataldi Gallo, ed., I Mezzari: Tra Oriente e Occidente (Genoa, 1988), pp. 15-17.

46. James C. Boyajian, Portuguese Trade in Asia under the Hapsburgs, 1580-1640 (Baltimore, 1993), p. 141; John Guy, Woven Cargoes: Indian Textiles in the East (London, 1998), p. 9.

47. Personal communication, Renato Barahona, Northwestern University. See, for example, T. Beaumont James, The Port Book of Southampton 1509-10 (Southampton, 1990), vol. 2, pp. 279-81, for commentaries on cargoes. Edward Roberts and Karen Parker, eds., Southampton Probate Inventories, 1497-1575 (Southampton, 1992), vol. 1, pp. 65-70; 150-2; 159-62; 165-7; 2: 244-52; 346-7; 358-9; Beverly Lemire, "Domesticating the Exotic: Floral Culture and the East India Calico Trade with England, c. 1600-1800," Textile: The Journal of Cloth and Culture, 1, no. 1 (2003), pp. 67-8. See also Chandra Mukerji, From Graven Images: Patterns of Modern Materialism (New York, 1983), chapter 5.

48. Berg, "In Pursuit of Luxury," pp. 116, 123. See also John Styles, "Product Innovation in Early Modern London," Past and Present, 168 (2000): pp. 124-169. Alfred P. Wadsworth and Julia de Lacy Mann observed that if "the first thought of European manufacturers had been prohibition, the second was imitation." The Cotton Trade and Industrial Lancashire, 1600-1780 (Manchester, 1931), p. 118.

49. Therle Hughes, English Domestic Needlework, 1660-1860 (London, 1961), p. 34; Dilys E. Blum, The Fine Art of Textiles: The Collections of the Philadelphia Museum of Art (Philadelphia, 1997), p. 56, Image 95, 1996-107-3, late seventeenth-century English embroidered beg hanging. Similar examples can be found in the Victoria \& Albert Museum. 
50. Lipovetsky, The Empire of Fashion, p. 20.

51. Georg Simmel, “Fashion,” International Quarterly 10 (1904), p. 136.

52. K. N. Chaudhuri, The Trading World of Asia and the English East India Company (Cambridge, 1978), pp. 96-7, 282. Aiolfi also provides a division into categories of imported cottons. Sergio Aiolfi, Calicos und gedrucktes Zeug: die Entwicklung der englischen Textilveredelung und der Tuchhandel der East India Company, 1650-1750 (Stuttgart, 1987). Similarly, in the second half of the seventeenth century, the Dutch VOC (Verenigde Oost-Indische Compagnie) imported into Europe on average 200,000 pieces of cotton textiles a year. However, cottons accounted for only one-third of the Dutch company's imports. See in particular Femme S. Gaastra, "The Textile Trade of the VOC: The Dutch Response to the English Challenge," South Asia 19/Special Issue (1996), pp. 85-95 and Michel Morineau, "The Indian Challenge: Seventeenth to Eighteenth Centuries," in Sushil Chaudhuri and Michel Morineau, eds., Merchants, Companies and Trade: Europe and Asia in the Early Modern Era (Cambridge, 1999), pp. 243-275.

53. Jás Elsner and Joan-Pau Rubiés, "Introduction," in Jás Elsner and Joan-Pau Rubiés, eds., Voyages and Visions: Towards a Cultural History of Travel (London, 1999), p. 50.

54. Negley B. Harte, "The Rise of Protection and the English Linen Trade, 1690-1790," in Negley B. Harte and Kenneth G. Ponting, eds., Textile History and Economic History (Manchester, 1973), and specifically on the banning of calicoes Natalie Rothstein, "The Calico Campaign of 1719-1721," East London Papers 7 (1964), pp. 3-21. See also Tim Keirn, "Parliament, Legislation and the Regulation of English Textile Industries, 16891714," in L. Davidson, Timothy Hitchcock, Tim Keirn and Robert D. Shoemakers, eds., Stilling the Grumbling Hive: The Response to Social and Economic Problems in England, 16891750 (Stroud, 1992), pp. 1-24; Raymond L. Sickinger, "Regulation or Ruination: Parliament's Consistent Pattern of Mercantilist Regulation of the English Textile Trade, 1660 1800," Parliamentary History 19, no. 2 (2000): pp. 211-32; Patrick K. O’Brien, Trevor Griffith, and Philip Hunt, "Political Components of the Industrial Revolution: English Cotton Textile Industry, 1660-1774," Economic History Review 44, no. 3 (1991): pp. 395423. For France see: Charles Woolsey Cole, French Mercantilism, 1683-1700 (New York, 1943).

55. See, for example, Rothstein, "The Calico Campaign”; Audrey W. Douglas, "Cotton Textiles in England: The East India Company's Attempts to Exploit Developments in Fashion 1660-1721," Journal of British Studies 8, no. 2 (1969), pp. 28-43.

56. Barbosa spent sixteen years in India working for the Portuguese government. His El Livro is an important testimony of the structure of trade and the relationship between Muslin merchants and Portuguese traders. See also Rudolf Pfister, "The Indian Art of Calico Printing in the Middle Ages: Characteristics and Influences," Indian Art and Letters, 13 (1939), p. 24.

57. Beverly Lemire, Fashion's Favourite: The Cotton Trade and the Consumer in Britain, 1660-1800 (Oxford, 1991), chapter 1.

58. Ada K. Longfield, "History of the Irish Linen and Cotton Printing Industry in the 18th Century," Journal of Royal Society of Antiquaries of Ireland 58 (1937), p. 26.

59. John Irwin, "Golconda Cotton Paintings of the Early Seventeenth Century," Lalik Kala 5 (1959): 11-48. 
60. Alexander I. Tchitcherov, India: Changing Economic Structure in the Sixteenth to Eighteenth Centuries: Outline History of Crafts and Trade (New Delhi, 1998), p. 72.

61. Until the 1960s it was believed that most Indian cotton textile production was painted, whilst the European production was printed. Research by Irwin, Schwarz and Floud has disproved it.

62. Peter C. Floud, "The Origins of English Calico Printing," Journal of the Society of Dyers and Colourists, 76 (1960), p. 275; Lemire, "Domesticating the Exotic," p. 71.

63. George Turnbull, A History of the Calico Printing Industry of Great Britain (Altrincham, 1947), p. 18.

64. Woolsey Cole, French Mercantilism, p. 165.

65. Katsumi Fukasawa, Toilerie et commerce du Levant d'Alep à Marseille (Paris, 1987), passim.

66. Olivier Raveux, "Espaces et Technologies dans la France Méridionale d"Ancien Régime: l'Example de l'Indiennage Marseillais (1648-1793)," Annales du Midi, 116, no. 246 (2004), p. 157; and Olivier Raveux , "Spaces and Technologies in the Cotton Industry in the Seventeenth and Eighteenth Centuries: The Example of Printed Calicoes in Marseilles," Textile History, 36, no. 2 (2005), pp. 131-45; Olivier Raveux, 'The Birth of the Calico Printing in Europe: The Case of Marseilles (1648-1692)' (Paper presented at the GEHN conference on "Global Histories of Economic Development: Cotton Textiles and Other Global Industries in the Early Modern Period'," Fondation Les Treilles, March 2006).

67. As in the case of Genoa where calico printing was introduced in 1690 by an Armenian. Marzia Cataldi Gallo, "Indiane e mezzari a Genova," in M. Cataldi Gallo (ed.), I Mezzari, p. 25.

68. Cited in Ernst Homburg, "From Colour Maker to Chemist: Episodes from the Rise of the Colourist, 1670-1800," in Robert Fox and Agustí Nieto-Galan, eds., Natural Dyestuffs and Industrial Culture in Europe, 1750-1880 (Canton, Mass., 1999), p. 221.

69. Geert Verbong, "The Dutch Calico Printing Industry between 1800 and 1875," in Fox and Nieto-Galan, eds., Natural Dyestuffs, p. 195.

70. Franco Brunello, L'Arte della Tintura nella Storia dell'Umanità (Vicenza, 1968), p. 215.

71. Homburg, "From Colour Maker to Chemist".

72. Cited in Florence M. Montgomery, Printed Textiles: English and American Cottons and Linens, 1700-1850 (New York, 1970), p. 16.

73. Stanley D. Chapman, "David Evans \& Co. The Last of the Old London Textile Printers," Textile History 14, no. 1 (1983), pp. 31-2; John Irwin and K. B. Brett, Origins of Chintz (London, 1970), pp. 3-5.

74. Stuart Robinson, History of Printed Textiles (London, 1969), p. 15. The pattern of migration in Europe and the circulation of useful knowledge that followed is explored in Lien Bich Luu, Immigrants and the Industries of London, 1500-1700 (Aldershot, 2005). 
75. Chaudhuri, Trading World of Asia, pp. 540-1; Gaastra, "Textile Trade of the VOC;" Dietmar Rothermund, "The Changing Pattern of British Trade in Indian Textiles, 17011757," in Chaudhuri and Morineau, eds., Merchants, Companies and Trade, pp. 276-86.

76. Giorgio Riello, 'The Rise of European Calico Printing and the Influence of Asia in the 17th- and 18th-centuries' (paper presented at the GEHN Conference on 'Cotton Textiles in the Indian Ocean', Pune, December 2005).

77. Wadsworth and Mann, Cotton Trade and Industrial Lancashire.

78. Rothstein, "Calico Campaign of 1719-1721," East London Papers 7 (1964), pp. 3 21; Keirn, "Parliament, Legislation and the Regulation of English Textile Industries," pp. 1-24; For a detailed analysis of the legislation on cotton in England see O'Brien, Griffith, and Hunt, "Political Components of the Industrial Revolution," pp. 395-423; for France see Woolsey Cole, French Mercantilism, p. 165.

79. Serge Chassagne, "Calico Printing in Europe before 1780," in Jenkins, ed., Cambridge History of Western Textiles, vol. 1, pp. 523-4. For a discussion on the geography of the French calico printing industry in the late eighteenth century see: Toiles de Nantes des XVIIe et XVIIIe Siècles (Mulhouse, 1978), pp. 8-9.

80. Robert Chenciner, Madder Red: A History of Luxury and Trade. Plant Dyes and Pigments in World Commerce and Art (Richmond, 2000), p. 70. For a comprehensive analysis of calico printing in Barcelona see James K. J. Thomson, A Distinctive Industrialisation: Cotton in Barcelona, 1728-1832 (Cambridge, 1992), in particular pp. 50-95.

81. F. W. Carter, "The Cotton Printing Industry in Prague, 1766-1873," Textile History 6 (1975), pp. 132-4, 145.

82. Tradesmen's records are filled with evidence of the various regional preferences of certain markets. After shipping blue and white cotton/linens to the American colonies, for example, Bristol merchants were informed that the blue colour of the patterned fabrics was too light; that in the colonial markets a darker blue was preferred. Lemire, Fashion's Favourite, 81. See also, Chapman and Chassagne, European Textile Printers, p. 82.

83. Cited in Floud, "Origins of English Calico Printing," p. 278.

84. Ibid. p. 279.

85. Luisa Dolza, "How Did They Know? The Art of Dyeing in Late-Eighteenth-Century Piedmont," in Fox and Nieto-Galan, eds., Natural Dyestuffs, pp. 139-45.

86. For a more detailed discussion see: Raveux, “Espaces et Technologies,” pp. 163-4.

87. The calico printer Ryhiner commented in 1766 that "because the use of painting instead of printing demands a greater degree of skills and is much slower, which means that even granted all things equal we could never adopt their methods, for we lack skilled craftsmen and could not keep the maintenance costs so low." Cited in Berg, "In pursuit of luxury," p. 115.

88. Robinson, History of Printed Textiles, 18. 
89. Good research on the relationship between printing on paper and printing on cotton has been done in France where in the 1920s and 1930s Henri Clouzot published seminal volumes on both topics. Henri Clouzot and Charles Follot, Histoire du Papier Peint en France (Paris, 1935). More recently Josette Brédif has considered the issue of design and artistic production on paper and cotton. Josette Brédif, "Etude des Similitudes de Motifs entre Toiles Imprimées et Papier Peints en France dans la Seconde Moitié du XVIIIe Siècle," in Claire Piguet and Nicole Froidevaux, eds., Copier-Coller. Papiers Peints $d u$ XVIIIe Siècle. Actes du Colloque de Neuchâtel, 8-9 Mars 1996 (Neuchâtel, 1998), pp. $143-54$.

90. Peter C. Floud, "The English Contribution to the Development of Copper-Plate Printing," Journal of the Society of Dyers and Colourists, 76 (1960), pp. 425-26.

91. Chassagne, "Calico Printing in Europe," 1: 520. Oberkamft's brother, however, had seen copper plates in use at Morat, near Neuchâtel in 1770. Floud, "The English contribution to the development of copper-plate printing," p. 427.

92. Chapman and Chassagne, European Textile Printers, p. 147.

93. Ibid., pp. 78-88.

94. Floud, "British Calico-printing," p. 4.

95. Robinson, History of Printed Textiles, 26. The process was adopted in Alsace and Jouy in 1797, in North America in 1809 and in Barcelona in 1817. Gilles Pitoiset, Toiles Imprimées, XVIIIe-XIXe Siècles (Paris, 1982), p. 8 and James K. Thomson, "Technology Transfer to the Catalan Cotton Industry: From Calico Printing to the Self-acting Mule," in Douglas A. Farnie and David J. Jeremy, eds., The Fibre that Changed the World: The Cotton Industry in International Perspective, 1600-1990s (Oxford, 2004), p. 252.

96. Edgard Depitre, La Toile Peinte en France au XVIIe et au XVIIIe Siècles: Industries, Commerce, Prohibitions (Paris, 1912), p. 5.

97. Lemire, "Domesticating the Exotic."

98. John Huyghen van Linschoten, The Voyage of John Huyghen van Linschoten to the East Indies: from the old English translation of 1598, edited by Arthur Coke Burnell, and Pieter Anton Tiele (London, 1885), vol. 1, p. 91. By India Linschoten intends Goa and the Malabar coast.

99. For examples of the adoption of Indian materials into Netherlands' material culture see: Lotika Varadarajan, South Indian Traditions of Kalamkari (Bombay, 1982), pp. 33-34 and Bianca M. du Mortier, Aristocratic attire: the donation of the Six family (Rijksmuseum, Amsterdam, 2000).

100. Jack Goody, The Domestication of the Savage Mind (Cambridge, 1977), p. 37.

101. Abdur Rahman, "Sixteenth- and Seventeenth-Century Science in India and Some Problems of Comparative Studies," in Changing Perspective in the History of Science (Boston, 1973), p. 66. 
102. Nicolo d'Aristotile, Esemplario di lauori ... (Venice, 1529); John Taylor, The Needles Excellency: A New Booke Wherein are divers Admirable Workes wrought with the Needle ... (12th ed., London, 1640). See also Baker, Calico Printing and Painting, p. vii.

103. Clunas, Superfluous Things.

104. Hunt, Governance of Consuming Passions, p. 44.

105. Quoted in Chapman and Chassagne, European Textile Printers, p. 85.

106. John Cary, A Discourse Concerning the East-India Trade, Shewing it to be Unprofitable to the Kingdom of England ... (London, n. d.), p. 4. 